Article

\title{
Local Participation or Elite Capture in Sheep's Clothing? A Conundrum of Locally Led Development
}

\author{
Aidan Craney \\ Department of Social Inquiry, La Trobe University, Melbourne, VIC 3086, Australia; E-Mail: a.craney@latrobe.edu.au
}

Submitted: 13 June 2020 | Accepted: 6 August 2020 | Published: 25 November 2020

\begin{abstract}
This article discusses concepts of legitimacy and elite capture in locally led development through a case study of the Pacific-based Green Growth Leaders' Coalition (GGLC). GGLC is a fellowship of persons identified for their developmental leadership potential on issues of sustainability and economic growth. Members are recruited into an exclusive grouping dedicated to influencing positive developmental change through informal networks and political backchannels. With their membership representing people who both self-identify and are locally recognised as leaders, queries exist to the extent to which their efforts represent a shift towards greater ownership of developmental processes at local levels or simply reinforce elite capture of 'local voice' in the most aid-dependent region in the world. Rather than necessarily offering straightforward answers to questions of legitimacy and elite capture, the example of GGLC demonstrates how complex the notion of locally led development can be in practice.
\end{abstract}

\section{Keywords}

development; diplomacy; elite capture; local leadership; locally led development; Pacific

\section{Issue}

This article is part of the issue "Leadership and Political Change in Asia-Pacific" edited by David Hudson (University of Birmingham, UK), Nicolas Lemay-Hébert (Australian National University, Australia), Claire Mcloughlin (University of Birmingham, UK) and Chris Roche (La Trobe University, Australia).

(C) 2020 by the author; licensee Cogitatio (Lisbon, Portugal). This article is licensed under a Creative Commons Attribution 4.0 International License (CC BY).

\section{Introduction}

Definitions of local leadership in development discourse are quite broad. For example, in Booth and Unsworth's influential article, 'Politically smart, locally led development,' the authors note that their conception of locally led projects are those that are owned, negotiated and delivered by "locals (broadly defined) [who] are more likely than outsiders to have the motivation, credibility, knowledge and networks to mobilise support, leverage relationships and seize opportunities" (2014, p. 13). This broad definition focuses on those with sufficient political capital to gather the support of donors, policymakers and others who can implement reforms, whether also local or outsider. Beyond general characteristics no distinctions are made, such as between wealthy, educated, urban people and those living subsistence lives in rural areas. Although there is a clear implication that local leadership consists of those individuals or coalitions with a grounded understanding of the lived realities of local peoples, this is not explicitly stated.

Surprisingly little has been written of where concepts of local leadership and grassroots leadership may conflict or overlap. Local leadership connotes connection of the leader to understandings of the livelihoods needs and political economy of local spaces but bypasses discussion of how deep this connection runs and how legitimacy is demonstrated at the grassroots level. This is not to say that this matter has not been addressed at all. Mohan and Stokke, for example, critique "the new localism in development studies [which] has tended to essentialise the local as discrete places that host relatively homogeneous communities or, alternatively, constitute sites of grassroots mobilisation and resistance" (2000, p. 264) and argue for deeper understandings of the political economy of local spaces. Another space where these ideas are discussed is in McGuinness' edited volume, Local First: Development for the Twenty-First Century 
(2012). Rather than writing of development that is locally led, owned or delivered the authors instead refer to 'Local First' practices that acknowledge power differentials not only between donor agencies and international Non-Government Organisations (NGOs) on one side and a generic conception of the 'local' on the other, but also at the local level. Hayman, particularly, writes of Local First development practices as incorporating not only central governments but also "coordinated but pluralistic provision by a range of local organisations-NGOs, entrepreneurs, lower tiers of government and other forms of citizen association for the remainder" (Hayman, 2012).

In this article, I interrogate notions of legitimacy and representation in relation to locally led development. To illustrate my argument, I draw on the example of the Green Growth Leaders' Coalition (GGLC). GGLC is an invitation-only fellowship of like-minded individuals living and working in the Pacific islands' region seeking to collaborate on strategies for advancing a vision of economic growth and development that is environmentally sustainable and amplifies Pacific cultural values. Drawing its members from high offices in government, development organisations, faith-based organisations, academia, the private sector and civil society groups, it is a prime example of an elite, locally led development initiative.

The article is divided into five sections. First, I discuss literature related to the extent to which local elites are seen to enhance or impede the widespread dispersion of benefits related to development interventions. I then provide information about GGLC, including its membership composition, to contextualise its operations as a locally led development initiative as well as the action research method by which I collected data. Next, I engage literature that discusses how leadership is contemporarily and historically conceptualised in the Pacific islands' region, including reference to literature on common traits of leadership in countries with small populations. I then use the case of GGLC to problematise the potential for a singular vision of what constitutes locally led development, as well as the role of elites in driving or impeding developmental gains at grassroots level. I conclude with reflections on how development donors and multilateral organisations could improve practices of supporting locally led development in ways that include and bring benefit to non-elites.

\section{Elite Capture in 'Locally Led' Development Interventions}

Questions of elite capture in relation to locally led development are not new. Cooke and Kothari's edited volume, Participation: The New Tyranny? (2001), expressly challenged notions that development interventions that espouse values of participation and inclusion are, by nature, participatory and inclusive. As Cornwall (2003) has noted with regard to the inclusion of women's voices in development interventions and Nyamugasira (1998) of faith placed by Northern NGOs in the capacity of Southern NGOs to represent local concerns, ideas of participation and whose voice counts can and often are exclusive of all but a small subset of any population. Mohan (2006), too, has cautioned against conflating the views of local elites with those affected by development initiatives at grassroots level. Often it is the opinions and experiences of well-educated and well-connected men, in particular, whose voices are privileged as those of the 'local.'

Although there are clearly problems of representation whenever a homogenised subset-whether by gender, education, ethnicity or any other marker-assumes authority as a voice for a heterogeneous group, it is unclear to what extent local elites improve or impede developmental gains for citizens at grassroots level. There are those who consider the inclusion of local elite voices in development planning as inherently problematic, reinforcing power imbalances and undermining attempts to distribute developmental benefits equitably (Lewis \& Hossain, 2008; Paffenholz, 2015; Waheduzzaman, As-Saber, \& Hamid, 2018). Others contend that while this may be true of some elites, others explicitly work to ensure developmental benefits are widespread (Dasgupta \& Beard, 2007; Mansuri \& Rao, 2004), and that involving elites in intervention planning and implementation alongside non-elites can improve social capital for both groups (Abe, 2009; Lund \& Saito-Jensen, 2013). Platteau (2004) argues that elite capture of projects does not necessarily mean that the benefits of interventions are thinly spread, though he advocates for the tight control of funds release by donors in a manner that runs counter to principles of locally led development.

Within the scholarship on elite capture in development interventions, a growing literature discusses greater nuance in the participation of elites and non-elites in achieving long-term change, noting how including both can increase social capital and that efforts to empower non-elites requires commitment to structural change beyond the parameters of isolated interventions (Musgrave \& Wong, 2016; Rigon, 2014; Sheely, 2015; Warren \& Visser, 2016; Wong, 2010). Wong (2010), in a comparison of development interventions-one which excluded local elites from decision-making processes and another that co-opted their engagement-notes that while excluding the elite does not diminish their influence, explicitly utilising their influence risks compounding their power in ways that may negatively impact on non-elites. He notes "the 'counter-elite' and 'coopt-elite' approaches should not be seen as 'either-or"' (Wong, 2010, p. 15) and suggests that judicious incorporation of elite views into development planning in a manner that can critique their perspectives and include nonelites provides a better blueprint for local participation both in discrete interventions and in shaping long-term structural change. Wong's approach mirrors that of thinking and working politically, which recognises that there are competing interests in any development intervention 
or reform effort, and that while developmental change requires reforming social and political structures achieving such reform requires co-opting the will of local people of influence (Teskey, 2017; TWP Community, 2016).

It is worth noting that the papers examining elite participation in development mentioned above tended to focus on discrete development projects with clear aims and intended processes. GGLC possesses neither of these. As I discuss below, its aim is a deliberately broad vision of an environmentally sustainable, economically prosperous, sovereign developmental future for Pacific peoples. It is a development project that does not adhere to heuristic categories such as 'big D/little d' or 'intentional/immanent' development but straddles and muddies such categories, exposing their reliance upon one another (Lewis, 2019).

\section{Context: Leaders and the Green Growth Leaders' Coalition}

The discussion in this article of GGLC as an example of a locally led development initiative is based on data drawn through an action research project that was conducted with GGLC that began in 2016. The action research project was aimed at providing insights and guidance about the process, logic and achievements of GGLC to its secretariat based at the International Union for the Conservation of Nature Oceania office (IUCN), its' funder, the Pacific Leadership Program (PLP) and GGLC, itself. While consent has been provided for the use of quotations in this article, it has not been provided for attribution of the quotations so they are completely deidentified.

GGLC was established in 2012 as a coalition of individuals sharing a commitment to advancing sustainable, locally led development in the Pacific islands' region. Membership of GGLC is by invitation from the secretariat based at the IUCN. Members are drawn from the upper ranks of a cross-section of government, industry and society. Although the vast majority of members are indigenous to Pacific states, this is not a requirement of membership. Individual members are identified and recruited based on two criteria: expected leadership capacity in their fields in the proceeding five years; and recognition of holding a broad shared outlook with other members that Pacific peoples should be responsible for envisioning and enacting their developmental futures in a way that is environmentally sustainable. The latter criterion is fundamental to the ambitions of GGLC. There is a recognition from members of a mission-like shared sense of purpose, with members remarking to me that this transcended differences of nationality, workplace affiliation and even philosophical outlooks. This shared sense of purpose for driving locally led development in the Pacific is an extension of previous articulations by seminal Pacific thinkers such as Wendt (1976), Hau'ofa (1994) and Crocombe, who stated: "Pacific people are not only entitled to, but obliged to, be actively in- volved to the fullest possible extent in shaping their own future" (Crocombe, 1975, p. 1).

Unlike East Asian concepts of green growth that are tied to attempts to use technology to improve a double bottom line of economic growth and environmental sustainability (Kim \& Thurbon, 2015; Moon, 2010), the GGLC approach to green growth is one that seeks to apply Pacific cultural values of environmental stewardship and sovereignty to achieve livelihood benefits for Pacific peoples (Dornan, Morgan, Newton Cain, \& Tarte, 2018). Governed by the IUCN and funded by the Australian Aid program through the PLP, it facilitated annual meetings at multi-day retreats for members from 2012 until funding ceased with the closure of PLP at the end of 2017. These annual meetings allowed for multi-day conversations utilising the Pacific talanoa method that allows for emergent discussion with no fixed agenda (Halapua, 2000). As has been discussed elsewhere (Craney \& Hudson, 2020), annual meetings provided an opportunity for members to consult with one another regarding development successes and challenges under the Chatham House rule (Chatham House, n.d.). One member described the benefit of the retreat format to me, saying, "It's not about networking...you network because of an opportunity....The talanoa is about building trust." The meetings also provided a space where members could set individual goals for how they individually hoped to progress locally led, sustainable development in the periods between annual meetings.

The action research approach took the form of an insider/outsider relationship (O'Keefe et al., 2014) with members of a three-person research team embedded in GGLC as participants, providing feedback to GGLC members, the secretariat and the donor. The purpose for the action research project was threefold: Monitoring the process and outcomes of the Coalition to the donor, documenting these processes and outcomes for insights to academic and practitioner development audiences, and providing critical feedback to the secretariat on how GGLC members understood the Coalition to function and their roles within it. Fundamental to the project was attendance at the 2016 and 2017 annual meetings in Fiji and Tonga, where I conducted formal and informal interviews with members. Attendance at the annual meetings allowed me to observe the frank discussion of members in the talanoa and contribute when called upon, reflecting upon themes that I had identified during the talanoa and through the process of the action research project in between meetings. Outside of the formal talanoa space I was able to develop rapport with Coalition members and have discussions that touched upon themes including their ideas for Pacific-led development, and the role and function of GGLC in achieving Pacific-led development.

Research continued beyond the annual meetings. During 2016 and 2017 the research team regularly engaged with Coalition members through face-to-face meetings, phone calls and emails asking for feedback 
on GGLC as a concept and its processes, as well as a survey instrument to track how they were progressing with their individual goals for advancing locally led, sustainable development. The depth of my engagement with members outside of annual meetings was largely dictated by the members, themselves, and the time that they had available within their typically busy schedules. Communication of preliminary findings, feedback from GGLC members and suggestions for improvements based on these were relayed on a regular basis to PLP and IUCN. Although GGLC has not formally dissolved, its operations have slowed to dormancy since funding ceased at the end of 2017. As a result, the action research process has naturally slowed, too, though the research team continue communication with IUCN and individual members on an ad hoc basis. GGLC is discussed in this article in the present tense as this is how the core members continue to discuss the initiative, reflecting their intention to revive the project in the future.

A defining feature of GGLC is that it operates through a hands-off process. It does not take an active role in facilitating development interventions nor proposing frameworks or planning documents. Its preferred method of influencing developmental change is through members utilising their personal and professional networks to shape how decision-makers inside governments, donor agencies and development organisations approach development interventions. To this end, it has claimed some success in influencing formal development plans at national and sub-national level in parts of the Pacific region amongst other measures, though its arms-length approach means that the causal effect of GGLC involvement in achieving these outcomes is unclear (Craney \& Hudson, 2020).

A particularly salient characteristic of GGLC's handsoff approach to influencing positive developmental change is that it turns the conventional diplomacydevelopment relationship on its head. International development policies and programs are regularly used to achieve diplomatic ends. Hillary Clinton has noted that "diplomatic objectives are often secured by gains in development" (2010, p. 14), while bilateral international development agencies in countries such as Australia and Canada have been absorbed by their foreign affairs departments under the guise of integration though more accurately representing assimilation (Yanguas, 2018, pp. 51-54). Although there is recognition of the growing role of development actors operating in diplomatic spaces (Constantinou \& Der Derian, 2010) and a growing community of academics and practitioners advocating for applying political economic understandings to interventions (Hudson \& Marquette, 2015; McCulloch \& Piron, 2019; Teskey, 2017; TWP Community, 2016), there is scant evidence of development initiatives centring diplomatic approaches of relationship-building and networking as a core tactic. Of course, development actors do employ these tactics in their ongoing engagement with donors and other development actors, but net- working is more generally used as a tool rather than a fundamental method of development work. For GGLC, however, networking and relationship-building is central both to how individual leaders are identified for membership, and the hands-off approach to influence that they favour.

Unlike bureaucratic interventions that connote the absence of politics and may avoid being critical of governments and implementing agencies (Ferguson, 1994), GGLC is highly political in its processes. Indeed, its approach of utilising personal and professional networks to attempt to effect change is a prime example of thinking and working politically (Leftwich, 2011). And while GGLC has not engaged in direct development interventions, nor even made public statements about positions that members hold, it is steadfast in its goal of Pacific-led environmentally sustainable development. Even when dealing with its major donor, GGLC asserted that locally led development required independence of thought, process and direction. That members participated in GGLC voluntarily in a way that did not risk the other social and professional positions that they held allowed members to assert independence and ensured that neither individual members nor the will of the collective was obsequious to the donor (Craney \& Hudson, 2020).

\section{Local Leadership in the Pacific}

By its very nature of being an invitation-only collective consisting of people identified as current and future developmental leaders, the membership of GGLC reflects elitism. In a region marked by social processes dictated by hierarchy-traditionally through chiefly and big man systems - it is important to understand the role of elites in leadership processes in the Pacific. Chiefs, big men, elders, nobles and people holding offices of power are generally held in high esteem throughout the region. Largescale policy and social reform planning needs the support of these people to have any hope of success.

On the surface this may appear to be a particularly undemocratic approach to leadership. As an Asian Development Bank report on Pacific governance from 2004 reads:

The modern and traditional systems of governance coexist uneasily. Whereas the former advocates individual merit, neutrality, equal participation, and the rights of the individual and the nuclear family, the latter demands priority and loyalty for kin and community, consensual and consultative values within the chief/"big men" traditional hierarchy, and traditionally defined roles for men and women. (Mellor \& Jabes, 2004, p. 16)

This viewpoint, while worded in a seemingly neutral manner, carries connotations of a deficit of critical civic engagement within Pacific cultures. It fails to acknowledge both the widespread social support for traditional governance systems and also the range of socio-cultural mea- 
sures of accountability that exist to support these systems. For example, of traditional Fijian governance practices, Ravuvu $(1983,1991)$ has written that they were highly democratic prior to European arrival, with chiefs being deposed if they failed to consult with and provide for their people. Fox (1967) has noted similar customs in Solomon Islands. Further, Ravuvu (1988) noted that the oppositional approach to politics that marks most Western liberal democracies is counterintuitive to traditional processes of decision-making and civic engagement in Pacific cultures. Members of the community seek to support leaders once a decision has been reached rather than seeking to expose flaws in the design or implementation of initiatives.

Claims that the Pacific is home to somewhat idyllic relations between leaders and the general public are not universally accepted, however. For example, Lawson (1996) has critiqued Ravuvu's claims of endogenous deliberative democracy as a wilfully naïve misrepresentation of consensus as a proxy for democracy that ignores how leaders can impose their influence. Lawson (1996) and Huffer (2005) have also commented that as many Pacific states gained sovereignty, elite classes co-opted colonial institutions that presented a façade of being democratic to buttress their own interests. Corbett (2015a) has noted that public perception of political leaders in the Pacific has also shifted from one of reverence in the 1960s and 1970s as more countries became independent to one where such leaders are now more likely to be associated with corruption and nepotism-a stereotype that he remarks does not adequately capture the good intentions that motivate most Pacific politicians and the challenges they face in achieving positive reforms in countries with small economies and limited bureaucracies. Perhaps the best articulation of the complexity of Pacific governance is provided by Duncan (2014), who notes: "The culture of the Pacific presents challenges to those attempting to bring about change. Communal and egalitarian values are held very strongly; although to an outsider, this sits oddly with the power that the elite hold within communities."

Part of the challenge in understanding the role of elites as development enablers or inhibitors in the Pacific in comparison to other parts of the world relates to the social closeness that marks relations of elites and non-elites. Even as systems designed to replicate liberal democracies become more embedded in Pacific societies and change how leadership is practiced, the smallness of Pacific states presents greater opportunity for connection between leaders and the general public (Teaiwa, 2005). This is a phenomenon that Corbett and Veenendaal have noted of politics in small states, writing, "Politicians are more than just legislators: They are family or clan members, friends, neighbours, or colleagues" (2019, p. 7). With all Pacific states, except for Papua New Guinea (PNG), considered to be small states due to having populations of less than one million people, the impact of interpersonal relationships in terms of governance and leadership may result in deeper understandings of the needs of people across boundaries of class, wealth and other social indicators (Corbett \& Veenendaal, 2018). Closeness of social ties arguably provides a layer of social accountability not possible in larger states in exposing leaders to the realities of everyday life for the general populace and in limiting their willingness to fracture social bonds.

This is not to suggest that the picture of leadership in the Pacific is uniformly utopic. Instances of civil unrest ranging from riots to civil conflict have been evident across the region in countries including Fiji, Kanaky/New Caledonia, PNG, Solomon Islands, Tonga and Vanuatu in the short period of the 21st century to date. The common theme across all of these instances being a lack of livelihood opportunities and access to resources (Lee \& Craney, 2019; Teaiwa, 2005). The necessary breakdown of political and social leadership at the time of these instances demonstrates that while the smallness of their populations may limit issues of social distance, institutions and leaders are not immune to criticism in these societies.

It needs to be noted that closer social ties do not equal shared backgrounds and struggles. Hau'ofa (2008) noted characteristics associated with a Pacific social elite across politics, business and civil society that delineates members from the broader public. He wrote: "The ruling classes of the South Pacific are increasingly culturally homogenous: they speak the same language, which is English [and] they share the same ideologies and the same material lifestyles" (Hau'ofa, 2008, p. 13). Consisting mostly of individuals with English-language university educations who operate as heads of government ministries, multilateral organisations, private corporations and beyond, Hau'ofa would likely apply this label to the members of GGLC. Although the elites that Hau'ofa wrote of were not limited to politics, parallels certainly exist between these elites and the politicians in small states that Veenendaal and Corbett argue utilise their "higher levels of education than the average citizen...to control the policy agenda" (2015, p. 539).

Local leadership in the Pacific can be seen to have fundamentally democratic traits but also be emboldened by distinct differences between elites and non-elites. Pacific leaders operate in a liminal space where they can be alternatively and simultaneously be seen as elites and/or trusted members of their communities. Whether relating to those with traditional hereditary titles or the emerging cosmopolitan global citizen, lesser social distance is evident in Pacific societies through the closeness dictated by their small sizes while greater social distance is perpetuated through differences in wealth, education and access to decision-making power, as well as the continuation of traditional practices of hierarchical deference. As Corbett (2015b) notes, leadership in the Pacific is very much the domain of elites.

The elitism of GGLC membership is not necessarily contradictory to it being genuinely locally led. Indeed, 
the vast majority of its members are citizens of Pacific states who have crafted careers based on their capacity to lead development institutions in the private, public and civil society sectors at sub-national, national, subregional and regional levels. If one were seeking examples of local development leaders in the Pacific each one of GGLC's members would be suitable for selection. The fact that the members of GGLC would be considered exemplars of local leadership in the Pacific does, however, beg questions of whether developmental leadership can or should be the domain only of elites.

\section{Discussion: Problematising Locally Led Development through the Example of GGLC}

The GGLC offers a particularly rich and complex case study for interrogating the risk of locally led development interventions falling prey to elite interests. On one hand the members of GGLC represent the epitome of an unrepresentative elite disconnected from the everyday livelihoods and poverty pressures that development has customarily been focused upon. GGLC is an invitationonly group displaying all of the traits of Hau'ofa's new social elite through its members' educations, professions and mobility. Further, its concerns for reshaping how development is conceived and practiced in the region are based on long-term visions that are the privilege of people not concerned with how they will put food on the table or uniforms on the backs of their schoolaged children. On the other hand, the members of GGLC come from a region marked by small populations and social closeness where hierarchy and representative leadership are not seen as anathema, and where accountability is addressed at street level or around the kava bowl on an ongoing basis. This reflects long-established norms of deliberatively democratic and representative civic engagement for Pacific peoples.

As heads of government ministries, industries, NGOs and more the GGLC certainly consists of the elite while remaining clearly locally led. In fact, GGLC represents what McCulloch and Piron (2019) identify as the most genuine form of local leadership in that it is an initiative that is entirely locally driven. GGLC was created by local people operating to a vision that they created through processes that they determined. Their commitment to adhering to their own vision of development and working through influence rather than distinct acts that demonstrate simpler lines of causality remained steadfast even when ongoing funding was at risk (Craney \& Hudson, 2020). It is important to note that the members of GGLC do not explicitly refer to themselves as 'locals,' though they do position themselves as such within conversations by discussing how Pacific values and ways of working compare and contrast with those of foreign governments and development agencies. Reflecting on the quality of discussion possible utilising talanoa as opposed to meetings with strict agendas, one member remarked that it was "conducive for greater, more intimate discus- sions. People spoke more freely, they felt more comfortable, there was an air of respect for one another. It was very Pacific. Everything was very Pacific and I appreciated that." Although they are important for being able to articulate ways of working that complement or contrast with development orthodoxy, concepts such as 'locally led development' should be acknowledged as outside impositions from the development community onto communities in receipt of development funding and assistance.

The greater question regarding the legitimacy of GGLC applies to the extent to which locally led development should represent grassroots developmental concerns. Development programs, policies and projects may be more efficiently implemented and have better results if they incorporate locals as designers, implementers and evaluators (Hayman, 2012) but if the locals engaged represent a cosmopolitan social elite there is a risk that such interventions will simply mirror those that would normally be designed by outsiders. This is one of the concerns at the heart of Mohan's appeals not to conflate elite and grassroots voices as an imaginary homogenised 'local' when he writes, "grassroots development...seeks to move the focus away from elite perspectives to those of the marginalized. It also opens up the question that if we can 'hear' these non-elite voices, will new social forms unfold?" (2006, p. 165). The challenge of working with elites was noted by staff within the PLP-the agency that funded GGLC-who noted that donor agencies providing support to local elites is suitable for some development initiatives but not all. On certain issues where the status quo needs to be disrupted, such as women's rights, driving change is easier with the support of local elites but their co-option needs to be managed carefully so as not to further marginalise activists or be met with fierce resistance (Denney \& McLaren, 2016).

At the heart of the concern related to the extent to which elites should be centred in locally led development interventions is the fear that elite voices will drown out those of the non-elite at grassroots level and use their influence to bolster their own status or financial position. As Paffenholz writes of elite involvement in peacebuilding: "Elites use the state as well as other hybrid governance arrangements as sources of income, power and legitimacy, penetrating these structures with the explicit aim of undermining them for the sake of their own well-being" (2015, p. 864). With corruption being a site of significant concern in Pacific states (Corbett, 2015a, 2015b), elite led development initiatives risk being seen as fronts for personal gain. Concerns of corruption, nepotism and the general use of political influence to improve personal ends are problematised by development initiatives such as GGLC, though. By avoiding project-based interventions it is unclear how members would strategise for their involvement to reap personal dividends. What benefits are there for elites in promoting an opaque vision of development? That members remained engaged for years despite limited awareness and acknowledgement of their influence in shaping 
development planning documents at sub-national and national levels (Craney \& Hudson, 2020) demonstrates that the members of GGLC are minimally concerned with personal gain through their involvement in the initiative. Either this or they have poor political nous-which is highly unlikely given their established reputations as leaders. Interestingly, when an earlier draft of this article was shared with some GGLC members for comment, one remarked that the exclusivity of only engaging leaders was at least partly motivated by a belief that if citizens saw trusted local leaders advocating for reforms then they would be more likely to support such efforts.

It is worth noting that matters of legitimacy and whether GGLC represents a case study in grassrootsengaged development or in elite capture of concepts of locally led development are not the concern of GGLC, itself. Again, this exposes a differentiation between how development efforts are framed by outsiders such as donors, evaluators and academics as opposed to by local persons embedded in development work through all facets of their lives. The members of GGLC recognise the exclusivity of the Coalition, but view this positively as a means through which members can develop their leadership skills and be motivated by the broad shared vision that they hold for a developmental future that is locally led and environmentally sustainable. Multiple members described to me that the annual meetings address a lack of space in the Pacific for leaders to engage in critical reflection and peer mentorship with one saying, "I don't think we have enough of those opportunities to critique ourselves." Another member remarked:

The Coalition is a space of people who believe in the same cause and who are engaged in different fora, but can come together in that space to discuss common issues, like common environmental issues, that we as the Pacific are facing.

They also recognise that exclusivity risks limiting their impact in the longer term. To address this, they do not express intentions to invite new members who do not exhibit leadership traits or to include leaders that are not seen to share their sense of purpose. Rather, they identify and offer mentoring to emerging leaders. This was reflected by a member who advocated "identifying potential leaders...as early as university" for mentoring by Coalition members with the potential to include them in the talanoa space. Given the hierarchical nature of most Pacific cultures, it is worth noting that some of the younger members who attended annual meetings that I observed expressed that sharing a space with established leaders was initially "very daunting," viewing these leaders as "very seasoned professionals" but that they became comfortable with support from these established leaders. One member told me that she was pulled aside during a tea break and advised: "[To] just speak my mind and not to worry." It is also worth noting that while men comprise approximately two-thirds of the membership of GGLC-with rotating membership making it impossible to determine fixed numbers - there is a rough gender parity amongst younger members. This reflects both the increasing influence women leaders are having in the region compared to even the recent past and also an awareness from the secretariat of the benefits of a more diverse membership base. Contrasted with these means by which GGLC appears to promote greater inclusivity in its recruitment practices, one member cautioned against expanding the selection criteria for membership too much. They stated that the Coalition needed to continually consider: "Being a little bit careful about how inclusive you are, so that it doesn't dilute the level of conversation, because we don't achieve our goals if that's the caseyou're constantly trying to bring them up to speed, etc."

By foregrounding diplomacy and networking as tools to achieve developmental ends GGLC explicitly engages the elite status of its members. This is not a collective that is seeking to pass itself as a grassroots organisation, nor does it seek to deny space for grassroots voices in developmental processes outside of its own work. Rather, it has worked to include the perspectives of grassroots citizens at times, such as in the formulation of a development plan for the Ha'apai region of Tonga (Craney \& Hudson, 2020). If there is any consideration that GGLC, as a locally led development initiative, presents itself as representative of grassroots voices this is a misrepresentation made totally on the behalf of the individual's imagination.

\section{Conclusion}

In recent years the push for development practices that are led, owned and delivered by locals has moved beyond an ethical philosophy to a concept that has gained favour as likely to lead to more effective and sustainable development outcomes (Andrews, Pritchett, Samji, \& Woolcock, 2015; Booth \& Unsworth, 2014; Hayman, 2012; McCulloch \& Piron, 2019). Coupled with the practice of a growing number of international NGOs relocating head offices from Western satellites to developing country bases (Williams, 2018), it is clear that the future for designing and implementing development initiatives must and will be driven by people at the local level. Never has this seemed more pertinent than in the shadow of the global Covid-19 pandemic, which has demonstrated that human movement across international borders is not as free as it previously seemed and that the engagement and embeddedness of foreign actors can be disrupted at short notice. This necessitates an increased focus from donors and multilateral organisations about how they can best support development initiatives that are genuinely locally led, owned and driven.

Definitions of locally led development remain opaque, though. Are all initiatives that include the participation of local peoples-of whatever status and to whatever extent-examples of locally led development? Should participation be representative of a broad swathe 
of communities or will inclusion of limited subsets of the population suffice?

This is an issue for consideration of donors and multilateral organisations much more so than for local development actors-elite and non-elite, alike. Supporting locally led development should not be an exercise of funding initiatives advanced by local citizens followed by ticking a box related to engaging the voice of locals. True support for locally led development requires an acknowledgement of the plurality of voices at local level and concerted effort needs to be made to capture the voices of peoples from different walks of life. Hayman's (2012) vision of Local First development that captures perspectives from a cross-section of society offers some guidance in how to achieve this in a way that seeks to empower the political capital of the broader community rather than just relying on the political capital of already established leaders to promote change (Booth \& Unsworth, 2014). Further, commitment to locally led development includes being aware of whose participation is not being included and why, recognising that some voices may not need to be included while others should be but cannot for various reasons.

The example of GGLC demonstrates the need for foreign agencies to critically contemplate who is meant by 'the local' and how a diversity of voices and experiences are captured. The example of GGLC should be understood as complex and not representative of other locally led development initiatives. Unlike most initiatives, it does not support specific projects, have fixed goals or operate with a staff reliant on donor funding for their livelihood. Further, it needs to be recognised that the political and economic context that it operates within is specific to its locality. The smallness of Pacific states makes discussions about elite capture and locally led development in the region very different from similar conversations in large and very large states.

In this article I do not attempt to offer a set of guidelines for what local leadership should look like and who it should involve. Neither am I interested in providing a judgement on the extent to which GGLC presents as locally led and representative of Pacific communities. Instead I seek to highlight the important point that who and what is considered as local leadership is dependent on context, content and the subjective concerns of those engaging with ideas of local leadership from practical or philosophical perspectives.

\section{Acknowledgments}

I would like to acknowledge the members and secretariat of GGLC for their time and commitment to the action research process, as well as comments on an earlier draft of this article. I would also like to thank the other members of the action research team, David Hudson and Dawn Gibson. I am grateful to the two anonymous reviewers whose comments markedly improved the work presented. Any errors are my own.

\section{Conflict of Interests}

The author of this article was employed as an action researcher of GGLC from 2016 to 2017 through the auspices of PLP. They have continued in an unpaid capacity since 2018.

\section{References}

Abe, A. (2009). Social capital formation and local capture in decentralisation: The case of Zambezia, Mozambique. Progress in Development Studies, 9(1), 63-79.

Andrews, M., Pritchett, L., Samji, S., \& Woolcock, M. (2015). Building capability by delivering results: Putting Problem-Driven Iterative Adaptation (PDIA) principles into practice. In A. Whaites, G. Teskey, S. Fyson, \& E. Gonzalez (Eds.), A governance practitioner's notebook: Alternative ideas and approaches (pp. 123-133). Paris: OECD.

Booth, D., \& Unsworth, S. (2014). Politically smart, locally led development. Overseas Development Institute. Retrieved from https://www.odi.org/sites/ odi.org.uk/files/odi-assets/publications-opinionfiles/9204.pdf

Chatham House. (n.d.). Chatham House rule. Chatham House. Retrieved from https://www.chathamhouse. org/chatham-house-rule

Clinton, H. (2010). Leading through civilian power: Redefining American diplomacy and development. Foreign Affairs, 89(6), 13-24.

Constantinou, C. M., \& Der Derian, J. (2010). Sustaining global hope: Sovereignty, power and the transformation of diplomacy. In C. M. Constantinou \& J. Der Derian (Eds.), Sustainable Diplomacies. Basingstoke: Palgrave Macmillan.

Cooke, B., \& Kothari, U. (2001). Participation: The new tyranny? London: Zed Books.

Corbett, J. (2015a). Being political: Leadership and democracy in the Pacific Islands. Honolulu, HI: University of Hawai'i Press.

Corbett, J. (2015b). "Everybody knows everybody": Practising politics in the Pacific Islands. Democratization, 22(1), 51-72.

Corbett, J., \& Veenendaal, W. (2018). Democracy in small states: Persisting against all odds. Oxford: Oxford University Press.

Corbett, J., \& Veenendaal, W. (2019). Why small states are beautiful. Political Insight, 10(1), 4-8.

Cornwall, A. (2003). Whose voices? Whose choices? Reflections on gender and participatory development. World Development, 31(8), 1325-1342.

Craney, A., \& Hudson, D. (2020). Navigating the dilemmas of politically-smart, locally-led development: The Pacific-based Green Growth Leaders' Coalition. Third World Quarterly. Advance online publication. https://doi.org/10.1080/01436597.2020.1773256

Crocombe, R. (1975). Seeking a pacific way. In S. Tupouniua, R. Crocombe, \& C. Slatter (Eds.), The pacific 
way: Social issues in national development. Suva: Fiji Times and Herald.

Dasgupta, A., \& Beard, V. (2007). Community driven development, collective action and elite capture in Indonesia. Development and Change, 38(2), 229-249.

Denney, L., \& McLaren, R. (2016). Thinking and working politically to support developmental leadership and coalitions: The Pacific leadership program (DLP Research Paper 41). Birmingham: Developmental Leadership Program. Retrieved from https://res. cloudinary.com/dlprog/image/upload/jsBVHw1Psu A0yzYpU33cCRJIGLRbEG9kSt4qNXDJ.pdf

Dornan, M., Morgan, W., Newton Cain, T., \& Tarte, S. (2018). What's in a term? "Green growth" and the "blue-green economy" in the Pacific Islands. Asia \& The Pacific Policy Studies, 5, 408-425.

Duncan, R. (2014, June 26). Reflections on constraints to growth in Pacific Island countries, keynote address at the 2014 Pacific update. Devpolicy Blog. Retrieved from https://bit.ly/3cuHFpw

Ferguson, J. (1994). The anti-politics machine: "Development" and bureaucratic power in Lesotho. The Ecologist, 24(5), 176-181.

Fox, C. E. (1967). The story of the Solomons. Taroaniara: DOM Publications.

Halapua, S. (2008). Talanoa process: The case of Fiji. Honolulu, HI: East-West Centre. Retrieved from http://unpan1.un.org/intradoc/groups/public/ documents/un/unpan022610.pdf

Hau'ofa, E. (1994). Our sea of islands. The Contemporary Pacific, 6(1), 148-161.

Hau'ofa, E. (2008). The new South Pacific society: Integration and independence. In E. Hau'ofa (Ed.), We are the ocean: Selected works (pp. 11-24). Honolulu, $\mathrm{HI}$ : University of Hawai'i Press.

Hayman, C. (2012). Introduction: Local first-A proposal for development in the twenty-first century. In K. McGuinness (Ed.), Local first: Development for the twenty-first century (pp. 13-43). London: Peace Direct.

Hudson, D., \& Marquette, H. (2015). Mind the gaps: What's missing in political economic analysis and why it matters. In A. Whaites, E. Gonzalez, S. Fyson, \& G. Teskey (Eds.), A governance practitioner's notebook: Alternative ideas and approaches (pp. 67-82). Paris: OECD.

Huffer, E. (2005). Governance, corruption, and ethics in the South Pacific. The Contemporary Pacific, 17(1), 118-140.

Kim, S.-Y., \& Thurbon, E. (2015). Developmental environmentalism: Explaining South Korea's ambitious pursuit of green growth. Politics and Society, 43(2), 213-240.

Lawson, S. (1996). Tradition versus democracy in the South Pacific: Fiji, Tonga and Western Samoa. Cambridge: Cambridge University Press.

Lee, H., \& Craney, A. (2019). Pacific youth, local and global. In H. Lee (Ed.), Pacific youth: Local and global futures (pp. 1-32). Canberra: ANU Press.

Leftwich, A. (2011). Thinking and working politically: What does it mean? Why is it important? And how do you do it? Paper presented at Politics, Leadership and Coalitions in Development: Policy Implications of the DLP Research Evidence, Research and Policy Workshop, Frankfurt, Germany.

Lewis, D. (2019). 'Big D' and 'little d': Two types of twenty-first century development? Third World Quarterly, 40(11), 1957-1975. https://doi.org/10.1080/ 01436597.2019 .1630270

Lewis, D., \& Hossain, A. (2008). A tale of three villages: Power, difference and locality in rural Bangladesh. Journal of South Asian Development, 3(1), 33-51.

Lund, J. F., \& Saito-Jensen, M. (2013). Revisiting the issue of elite capture of participatory initiatives. World Development, 46, 104-112.

Mansuri, G., \& Rao, V. (2004). Community-based and driven development: A critical review. World Bank Research Observer, 19(1), 1-39.

McCulloch, N., \& Piron, L. H. (2019). Thinking and working politically: Learning from practice. Development Policy Review, 37, 1-15.

McGuinness, K. (Ed.). (2012). Local first: Development for the twenty-first century. London: Peace Direct.

Mellor, T., \& Jabes, J. (2004). Governance in the Pacific: Focus for action 2005-2009. Manila: Asian Development Bank.

Mohan, G. (2006). Beyond participation: Strategies for deeper empowerment. In B. Cooke \& U. Kothari (Eds.), Participation: The new tyranny? (pp. 153-167). London: Zed Books.

Mohan, G., \& Stokke, K. (2000). Participatory development and empowerment: The dangers of localism. Third World Quarterly, 21(2), 247-268.

Moon, T. H. (2010). Green growth policy in the Republic of Korea: Its promise and pitfalls. Korea Observer, 41(3), 379-414.

Musgrave, M. K., \& Wong, S. (2016). Towards a more nuanced theory of elite capture in development projects: The importance of context and theories of power. Journal of Sustainable Development, 9(3), 87-103.

Nyamugasira, W. (1998). NGOs and advocacy: How well are the poor represented? Development in Practice, 8(3), 297-308.

O’Keefe, M., Sidel, J. T., Marquette, H., Roche, C., Hudson, D., \& Dasandi, N. (2014). Using action research and learning for politically informed programming (DLP Research Paper 29). Birmingham: Developmental Leadership Program. Retrieved from https://res. cloudinary.com/dlprog/image/upload/dbQidJRc708a BRVYk5oSlolANrTwkox1wILuGkS6.pdf

Paffenholz, T. (2015). Unpacking the local turn in peacebuilding: A critical assessment towards an agenda for future research. Third World Quarterly, 36(5), 857-874.

Platteau, J.-P. (2004). Monitoring elite capture in 
community-driven development. Development and Change, 35(2), 223-246.

Ravuvu, A. D. (1983). Vaka i Taukei: The Fijian way of life. Suva: Institute of Pacific Studies, University of the South Pacific.

Ravuvu, A. D. (1988). Development or dependence: The pattern of change in a Fijian village. Suva: Institute of Pacific Studies and the Fiji Extension Centre, University of the South Pacific.

Ravuvu, A. D. (1991). The facade of democracy: Fijian struggles for political control 1830-1987. Suva: Reader Publishing House.

Rigon, A. (2014). Building local governance: Participation and elite capture in slum-upgrading in Kenya. Development and Change, 45(2), 257-283.

Sheely, R. (2015). Mobilization, participatory planning institutions, and elite capture: Evidence from a field experiment in rural Kenya. World Development, 67, 251-266.

Teaiwa, T. (2005). Ethnicity and identity. In J. Henderson \& G. Watson (Eds.), Securing a peaceful Pacific (pp. 271-274). Christchurch: Canterbury University Press.

Teskey, G. (2017). Thinking and working politically: Are we seeing the emergence of a second orthodoxy? Massachusetts, MA: ABT Associates. Retrieved from https://www.abtassociates.com/insights/ publications/white-paper/thinking-and-workingpolitically-are-we-seeing-the-emergence-of

TWP Community. (2016). The case for thinking and working politically: The implications of 'doing development differently.' Maastricht: ECDPM. Retrieved from https://ecdpm.org/wp-content/uploads/CaseThinking-Working-Politically.pdf

Veenendaal, W., \& Corbett, J. (2015). Why small states offer important answers to large questions. Comparative Political Studies, 48(4), 527-549.

Waheduzzaman, W., As-Saber, S., \& Hamid, M. H. (2018). Elite capture of local participatory governance. Policy \& Politics, 46(4), 645-662.

Warren, C., \& Visser, L. (2016). The local turn: An introductory essay revisiting leadership, elite capture and good governance in Indonesian conservation and development programs. Human Ecology, 44, 277-286.

Wendt, A. (1976). Towards a new Oceania. Mana Review, 1(1), 49-60.

Williams, K. C. (2018). INGOs relocating to the global South. Brighton: Institute of Development Studies. Retrieved from https://www.ids.ac.uk/download. php?file=wp-content/uploads/2018/09/438-INGOsrelocating-to-the-South.pdf

Wong, S. (2010). Elite capture or capture elites? Lessons from the 'counter-elite' and 'co-opt-elite' approaches in Bangladesh and Ghana. (Working Paper No. 2010:82). Helsinki: World Institute for Development Economics Research. Retrieved from http://hdl. handle.net/10419/54126

Yanguas, P. (2018). Why we lie about aid : Development and the messy politics of change. London: Zed Books.

\section{About the Author}

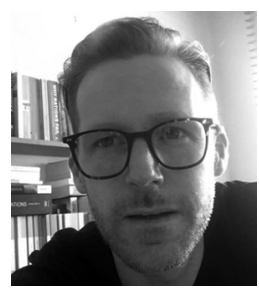

Aidan Craney is an Honorary Research Fellow with the Institute for Human Security and Social Change and a Lecturer in the Department of Social Inquiry at La Trobe University, as well as an International Development Consultant. His research looks at youth livelihoods and adaptive development practices in the Oceania region. 